ELORE (ISSN 1456-3010), vol. 19 - 2/2012.

Julkaisija: Suomen Kansantietouden Tutkijain Seura ry.

[http://www.elore.fi/arkisto/2_12/leisio.pdf]

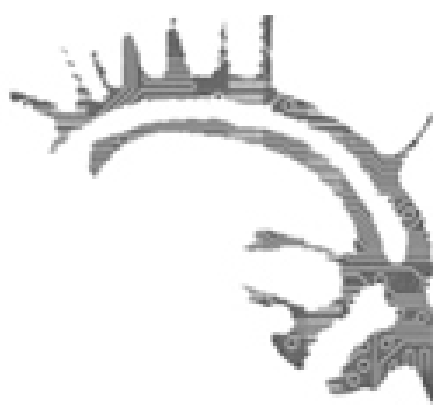

KATSAUS

\title{
MUTTI JA PEPU
}

\section{SKANDINAVIAN METSÄSUOMALAISEN RUOAN TAUSTAA SUOMESSA JA KARJALASSA.}

\section{Timo Leisiö}

Keski-Skandinavian syvimpien metsien kiinteän asutuksen käynnistivät finnet, jotka olivat muuttaneet sinne 1500-luvulta alkaen pääosin Savosta, Karjalasta, Hämeestä ja Keski-Pohjanmaalta, vaikka toki muidenkin maakuntien alueelta lähti väestöä länteen (Tarkiainen 1990; Nordmann 1994; Bladh 1995; Eles 1995). Finnet säilyttivät kulttuurissaan hyödyllisiksi kokemiaan vanhoja piirteitä, mutta hyödyttömäksi koettu unohtui ja korvautui skandinaaveilta lainatuilla aineksilla. Vaikka laululyriikka ja parannusloitsut ovat säilyneet 2000-luvulle, epiikka ja kantele ovat kadonneet. Muuan omaan aikaamme säilyneistä aineksista on varsin yksinkertainen mutti, metsäläisten jauhoruoka, jonka valmistus ja syönti ovat säilyneet sukuperinteiden kautta ja jonka taustoja pyrin tässä pohtimaan. Kirjoituksen tiedot pohjaavat vuosina 1986-1990 Ruotsin ja Norjan suomalaismetsiin tekemiini matkoihin, joten erityisiä lähdeviitteitä annan lähinnä vain Suomen osalta.

Eteläisen Taalainmaan Tyngsjössä vietetään vuotuisia muttijuhlia. Järjestäjät ovat sekä metsäsuomalaisten jälkeläisiä että toisen maailmansodan jälkeisiä ruotsinsuomalaisia. Tyngsjö oli 1500-luvun lopulta alkaen ollut finnealuetta. Finne-vaikutteet näkyvät muun muassa paikkojen nimissä. Yhtenä esimerkkinä on Vattaå-niminen kylä, joka nimi palautuu Vattuahoon (eikä ruotsin 'Vesijokeen' kuten pääväestö sen tulkitsee). Alueen ensimmäiset asukkaat olivat 1600-luvulla olleet Matti ja Kirsti, jotka sukutiedon mu- 
kaan jo olivat tunteneet mutin. Tyngsjön hautausmaan monien metsäfinnien rinnalla lepää Leisme Per Larsson (1822-1907), Fattigskogin seudun Tiaisia, suomalaismetsien ja koko Ruotsin maineikkaimpia viulisteja. Hänen pelimannikavereitaan oli Tyngsjön eteläpuolella avautuvan Värmlannin maakunnan mestari Lomiansguten 'Lumiais-Äijä' eli Per Jönsson (1816-1875). ${ }^{1}$ Koska mutti on osa metsäsuomalaista identiteettiä, KeskiRuotsin kaupoista saa edelleenkin ostaa erityistä muttijauhoa. Sitä valmistaa värmlanninsuomalaisten jälkeläisten ylläpitämä Stöpaforsin mylly paahdettuina kauraleseinä. Kilon jauhopussin selässä olevan mutin valmistusohjeen suomennos on:

Nyrkkipuuro 4-6 hengelle:

$6 \mathrm{dl}$ vettä, $1 / 2 \mathrm{~kg}$. jauhomaltaita, $1 \mathrm{tlk}$. suolaa.

Kun vesi kiehuu, jauhot kaadetaan kerralla kattilaan. Painellaan puulusikalla tai puurotikulla. Tarjoillaan paistetun vähäsuolaisen silavan kera. Vanhan tavan mukaan nyrkkipuuro keitetään laiskasti. (Stöpaforskvarn 2012.)

Erilaisissa kotiseutumuseoissa mutti kuuluu tarjottaviin perinneruokiin. Esimerkiksi Värmlannin Lekvattnetin pitäjän Karmenkynnassa ja Kvarntorpissa se pitää syödä oikeaoppisesti: "Kun keittovesi on höyrystänyt jauhot, mutti on valmis tarjottavaksi paistetun silavan, piimän ja puolukkahillon kera”. (Karmenkynna 2012.)

\section{MutTi SKANDinaviassa}

Julius Mägisten keräämän aineiston mukaan Värmlannin motti, motta, nävgröt 'nyrkkipuuro’ voitiin valmistaa ainakin kahdella tavalla. Metsälle ja metsätöihin lähteneillä oli tapana ottaa mukaan jauhoja ja piimää. Nälän tultua he tekivät tuohesta lipin tai kipon, jossa he sekoittivat jauhot piimään ja söivät ruoan kylmänä siltä istumalta. Jos seoksesta tuli kokkareinen, he söivät sen lusikalla. Tavallisempaa erityisesti talvella oli sytyttää tuli, keittää lipissä vesi, lisätä siihen jauhot ja antaa ruoan valmistua kokkareiksi.

Mutti näyttää olleen tunnettu kaikkialla, missä metsäfinnet olivat menneinä vuosisatoina asuneet. Ylä-Ruotsista luetellen ruokalaji oli tunnettu seuraavissa maakunnissa: Norlanti, Jemtlanti, Medelpad, Hälsinglanti, Taalainmaa, Gästrikland, Uplanti, Västmanlanti, Värmlanti sekä Kaakkois-Norjan Hedmark. Mutti oli oletettavasti tunnettu myös Dalslandissa sekä Länsi-Göötanmaalla, sillä metsäfinnejä oli muun muassa asunut Göteborgin pohjoispuolelta nousevilla metsävuorilla. On vaikea sanoa, kuka lopulta oli puhtaasti riikinruotsalainen, mutta esimerkiksi Jonas Bergman esitteli mutia 1980-luvulla kansanomaisena ruotsalaisruokana Hälsinglannin Ljusdalissa (motti) ja Färilassa (nävgröt), joista kummassakin oli aikanaan elänyt finnejä. 1930-luvulla noilla seuduin vesi kiehautettiin ensin ja lusikka pantiin keskelle pataa, johon oli kaadettu vehnä- ja ruisjauhoja. Jauhot olivat keittyneet sekoittamatta, jolloin ruoasta tuli lopulta paakkuista ja hienorakeista. Tämä jättää tosin auki kysymyksen, mihin padan keskelle laitettua lusikkaa lopulta tarvittiin. 
Kartta. Karkea esitys mutin skandinaavisesta levinneisyydestä jokilaaksojen välissä oleville metsäisillä vaaroilla asuvien metsäsuomalaisten keskuudessa. Kolmio osoittaa mutin tuntemuksen keskeisalueen.

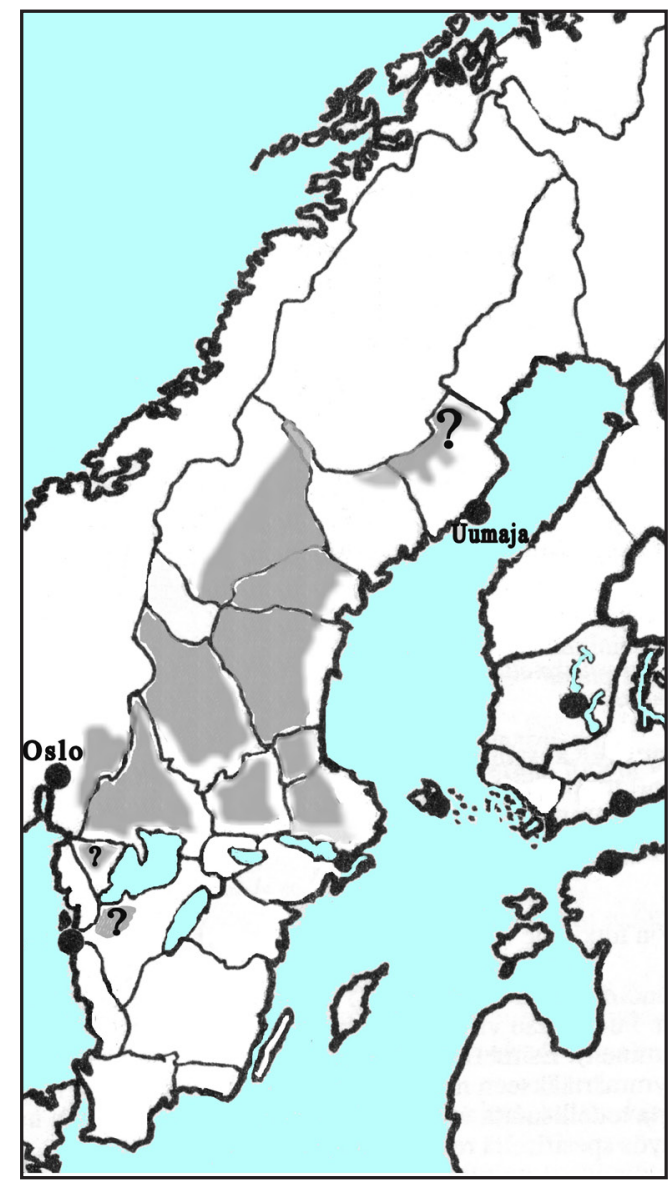

Läntisen Värmlannin ja kaakkoisen Norjan metsissä mutin nesteenä oli vanhastaan ollut kalan tai riistaeläimen keitinliemi, johon kiehumisen alettua lisättiin ruis-, kauratai ohrajauhoja. Lientä oli kaksi kertaa enemmän kuin jauhoja ja mausteena käytettiin suolaa. Vesi imeytettiin hämmentämättä lämpimällä liedellä jauhoihin. Tosin silloin tällöin tahnaa liikutettiin puisella kauhalla nimeltään mottimele. Tämän suomen muttimelaa mukailevan sanan kohde oli epäilemättä ollut sama kuin muutamissa ohjeissa esiintyvä 'jauhotikku'. Myös Värmlannissa muttiin oli kuulunut puolukkahillo (billo), käristetty sianliha ja piimä. Jälkipolvien maineeseen nostama Niittahon ( Niittyahon) Jussi olikin 1950-luvulla kummastellut nykyisiä keveitä ruokia ja ihastellut muttia, koska “se o' vahvoa ruokoa!". Perinteen elvyttäjille mutin, puolukan ja piimän kolmiyhteys on loukkaamaton, joten mutin kanssa ei Ruotsissa oikein uskalla juoda vettä tai olutta.

Julius Mägiste on lisäksi antanut tietoja Värmlannin finnien pepusta, joka tunnettiin kirjoitusasuina $р е р и$, pebbo ja рерри. Ruokalaji “tehtiin keitetyistä perunoista ja kaurajauhoista” tai puolukan ja jauhojen sekoituksesta, joka nautittiin kylmänä. Nyky-Norjan Gruessa рерро [lausuttuna pepu] on hyvin pienikokkareiseksi keittämällä höyrystynyttä muttia. Värmlannissa kerrotaan pepun olleen piimästä ja kaurajauhosta tehtyä velliä. Kun pepua tarjoiltiin penkillä olevasta puukaukalosta, sitä saatettiin kutsua myös 'penkkivelliksi' (Finnskogarna 2012). 
Internet-lähteet viittaavat siihen, että mutti on alkanut viime aikoina saada suosiota ennen kaikkea ravitsemuksesta kiinnostuneiden kuten laihduttajien keskuudessa. Tästä saa kuvan esimerkiksi hakusanoilla motti och fläsk sekä nävgröt. Ruoasta laihduttajien tapaan kiinnostuneille ihmisille Suomessa ja erityisesti Ruotsissa, jossa mutti aletaan tajuta ruotsalaiseksi ruoaksi ilman, että se enää kytkeytyy finne-väestöön.

\section{Mutti Suomessa}

Ilmar Talve on yleisellä tasolla kirjoittanut mutista seuraavaa:"Alkeellisimmat jauhoruoat valmistettiin kaukana sijaitsevilla työmailla sekä erä- ja merimatkoilla pelkästä raa’asta jauhosta ja vedestä, joihin lisättiin mausteeksi suolaa. Ruokaa voitiin syödä sellaisenaan, jolloin ruokaa kutsuttiin pepuksi, tai se keitettiin, useimmiten kalaliemessä kuten mutti." (Talve 1979.) Toivo Vuorela taas on kansanomaisia jauhoruokia esitellessään todennut, että mutti on hämäläisten ja keskipohjalaisten ruoka, joka keitettiin sakeaksi tahtaaksi ohrajauhoista. Sen eteläpohjalaisena vastineena on tikkuhöyry. Savolle ja sen lähialueille ominainen oli taas kylmään veteen sekoitettu pepu, jota riittävän kovaksi keitettynä "haukattiin kouraan puristetusta pallosta". (Vuorela 1976.)

Näihin tietoihin Talve oli tuonut lisänsä kuvatessaan, kuinka jauhoruokain vanhaan kerrostumaan kuuluva mutti sekoitettiin kiehuvaan veteen ja pepu kylmään veteen. Kummatkin ruoat ovat vanhempia kuin talkkuna, joka tehtiin esikeitetyistä ja sitten kuivatuista jauhoista (eikä raaoista kuten mutti ja pepu). Hänen mukaansa pepu oli tunnettu Viipurinlahden rannikolla, Etelä-Savossa, Laatokan Karjalassa, Pohjois-Hämeessä sekä paikoin Uudellamaalla ja Pohjanmaalla. Se oli puuromainen tahdas, joka syötiin kourasta. Talven mukaan mutti eli jauhomutti edustaa pepun lailla vanhakantaista ruokalajia retkievääksi ja töiden välipalaksi. Mutista on Itä-Suomesta vain hajatietoja. (Talve 1973.)

Kontiolahdella tunnettiin tilli eli mutti. Jos sen ohessa söi käristettyä sianlihaa, kyse oli "vanhan kansan mutista”. Tämän mutin levikki jää avoimeksi, mutta lähteessä se oli määritetty "savokarjalaiseksi” (Vuorela 1976). Se vastaa kaikilta osin finneväestön mottia: pataan kolme kuppia vettä, kuusi kuppia jauhoja ja suolaa. Ruokaa ei hämmennetty, mutta runsaan puolen tunnin keittämisen jälkeen sitä kieputettiin tikulla eli bierimellä. (Tämä vastaa siis finnien muttimeleä.) Tähän oman jatkonsa latasi Vuorela todetessaan, että Pohjois-Karjalassa mutti oli "sakea tahdas, joka valmistettiin kiehauttamalla lihanpalasia vähässä vedessä ja lisäämällä siihen ohrajauhoja." Lisäksi hänen mukaansa mutin synonyymejä olivat köpötes, tikkupuuro, tikkuhöyry ja äkkinäinen, joita on esiintynyt maan eri puolilla. (Vuorela 1979.) Mainittakoon, että Väinö Karvinen mainitsee pohjoissavolaisten ruokien joukossa talkkunan ja metsäsuomalaistenkin tunteman rieskan, mutta yksikään tieto ei viittaa muttiin eikä pepuun (Karvinen 1939).

Muttia ei esiinny Nykysuomen sanakirjassa, ei Suomen kielen etymologisessa sanakirjassa eikä Suomen sanojen alkuperässä. Sitä ei myöskään ole mainittu nimeltä Suomen kansankulttuurin kartastossa, mutta sen osiossa "Talkkuna” Vuorela toteaa, että “[a]lkeellisimpia jauhoruokia valmistettiin sekoittamalla jauhot sellaisinaan kylmään veteen ---, ainoana mausteena suola. Jauhoista voitiin keittää myös niin sakea puuro, että sitä saattoi 
syödä kädestä". Ollaksemme tarkkoja, viimeisin lause vaatii korjauksen. Ilmaus "keittää myös niin sakea puuro" kohdistuu pepuun. Sen kuten myös mutin valmistus tapahtuu kiehuttamalla vesi, mutta ruoka ei valmistu keittämällä vaan höyrystämällä. Niin ikään pepu ei ole puuro vaan pepu: puuro on löysäksi keitetty, pepu tiukaksi höyrytetty. Tässä mielessä lause voidaan tulkita asuun " [j] auhot voitiin höyryttään niin sakeaksi pepuksi, että sen saattoi syödä kädestä”. (Vuorela 1976.)

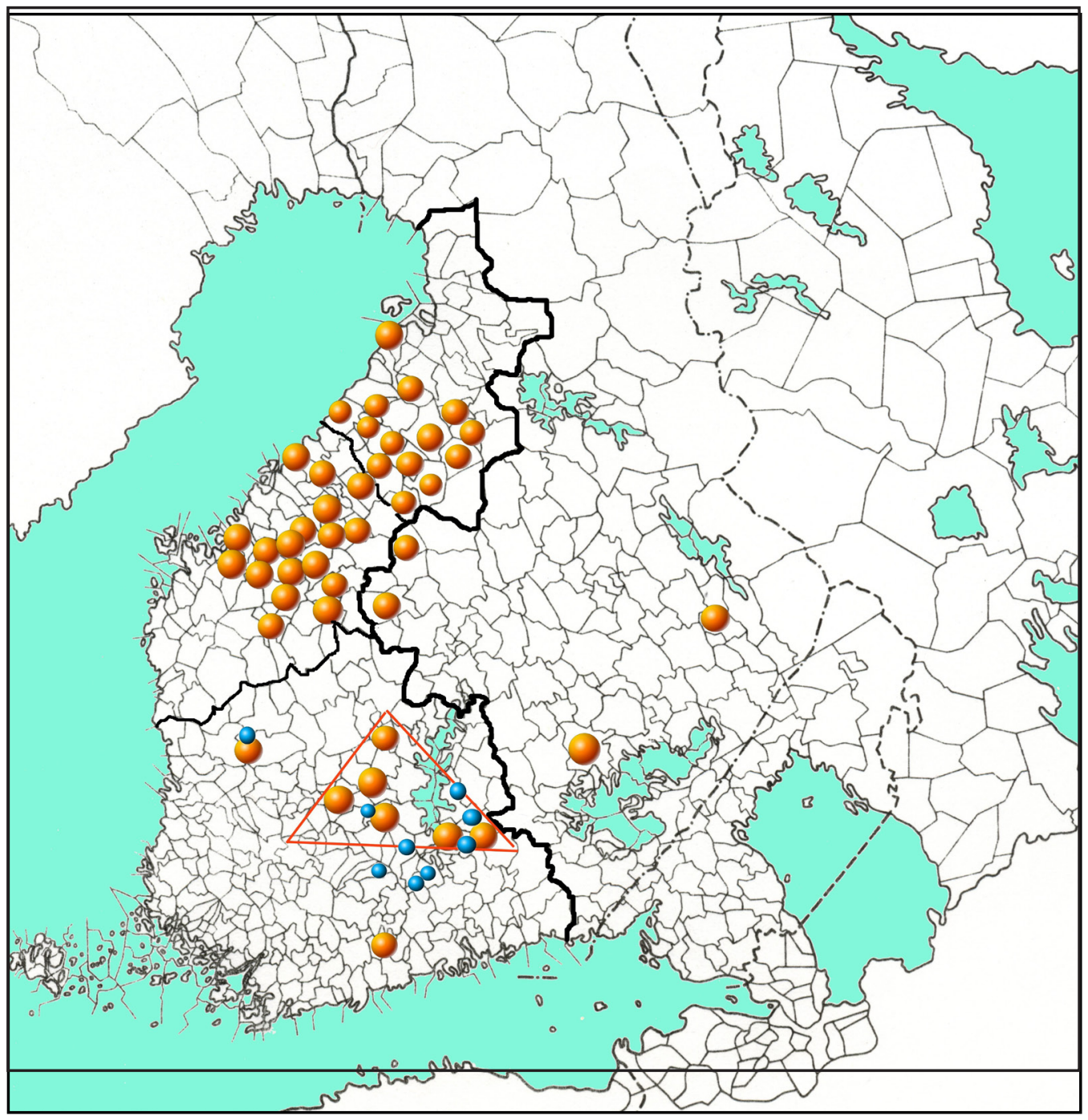

Mutin levikki Suomessa 1900-luvulla. Paksu musta viiva erottaa Länsi-Suomen Itä-Suomesta. Tietojen pääosa on Pohjanmaalta sekä Hämeen kolmiosta. Lisätietoja on oheisessa taulukossa. Tiedoista eteläisin on Nurmijärveltä ja itäisimmät ovat Kontiolahdelta ja Juvalta. Pienet siniset pallot tarkoittavat juotavaa muttia eli pellonpiimää. 
Suomen kansankulttuurin kartastossa esiintyy länsisuomalainen nimitys penkkivelli, joka tarkoittaa pirtin penkin päässä olevaan puupyttyyn kaadettua varijuurta eli vellin vahvuista hapanimelää juotavaa, jota voidaan myös lusikoida (Lampinen 1976, 100). Tässä valossa Värmlannin penkkivelli ei ollut pepua vaan länsisuomalaista varijuurta.

Mutin levikki lähinnä Sanakirjasäätiön tietojen valossa:

\begin{tabular}{|c|c|}
\hline Maakunta: & Pitäjät \\
\hline Pohjois-Pohjanmaa & Alavieska, Haapajärvi, Haapavesi, Kalajoki, \\
\hline & $\begin{array}{l}\text { Kärsämäki, Merijärvi, Nivala, Piippola, Pulkki- } \\
\text { la, Reisürvi, Sievi, Siikajoki, Vihanti, Ylivieska. }\end{array}$ \\
\hline Keski-Pohjanmaa & $\begin{array}{l}\text { Halsua, Kannus, Kaustinen, Kälviä, Toholam- } \\
\text { pi, Veteli }\end{array}$ \\
\hline Etelä-Pohjanmaa: & $\begin{array}{l}\text { Alahärmä, Alajärvi, Evijärvi, Kauhava, Kortes- } \\
\text { järvi, Lappajärvi, Lapua, Lehtimäki, Nurmo, } \\
\text { Oravainen, Vöyri, Ylihärmä. }\end{array}$ \\
\hline Pohjois-Karjala: & Kontiolahti. \\
\hline Etelä-Savo: & Juva. \\
\hline Keski-Suomi: & Karstula, Kinnula. \\
\hline Häme: & Asikkala, Heinola, Kuorevesi, Luopioinen. \\
\hline Satakunta: & Eräjärvi, Jämijärvi, Kangasala. \\
\hline Uusimaa: & Nurmijärvi \\
\hline
\end{tabular}

Paikoin Pohjanmaalla, muun muassa Kaustisilla, Ala- ja Ylivieskassa sekä Vihannissa, pepu on erotettu mutista sillä perusteella, että pepu tarvitsi enemmän jauhoja ja vähemmän vettä kuin mutti. Toisin sanoen pepu on tiukkaa, kuivaa ja pienikokkareista muttia. Lapualla taas hyvin sakea velli oli puuroa ja hyvin sakea puuro muttia. Tässä valossa onkin loogista jatkaa, että hyvin sakea mutti on pepua. Tällainen luokitus saattoi toimia aiemmin Pohjanmaalla, mutta se ei välttämättä ollut muualla tunnettu.

Ylä-Satakunnassa ja eteläisessä Hämeessä mutin rinnalla on käytetty sanoja syötävä taikina ja navero. Jälkimmäinen on lähellä ruotsin sanaa nävgröt, 'nyrkkipuuro', eli kokkareinen muttitahnas. Navero oli tunnettu myös Etelä-Savon Juvalla, jossa sen rinnakkaisnimityksinä olivat nyrkkitalkkuna ja kouratalkkuna. (Navero-sana saattaa liittyä myös pohjalaisen Lappajärven narikka 'mutti' sanaan.) Merkittävä seikka on se, etteivät juvalaiset tunne ruokaan erityisesti liittynyttä muttia, vaikka he hieman mietittyään muistavat sen tarkoittaneen jotain "puuromaista ainetta kuten hilloa tai pakkautunutta tervaa esim. veneen pohjalla”. Lisäksi Juvan mutti tarkoitti 'perunaa', mikä saattaa olla pottu-sanan vaikutusta. Juvalla (ja Nurmijärvellä) on sanottu, että "parempi pieni mutti kuin tyhjä kuppi”. (Sanakirjasäätiön sanaliput.)

Näugröt-sanan erilaisten asujen esiintyminen Etelä-Savossa ja Hämeessä ei ole outoa, sillä monet Ruotsissa asuvat metsäsuomalaiset pitivät yllä suhteitaan suomenpuoleisiin sukulaisiinsa. Liike Pohjanlahden kahta puolta oli vilkkaampaa kuin on osattu arvella. Kuten olen muissa yhteyksissä todennut, näiden yhteyksien muistumana kaakkoisessa Norjassa oli 1900-luvun puolivälissä laulettu uudehkoja Suomesta tuotuja lauluja samaan 
tapaan kuin Savossa oli alettu viljellä kaksikielisiltä finneiltä omaksuttuja juomalauluja pöytäpuheineen ja maljannostoineen. (Leisiö 1995a, 1995b \& 1996.)

Itäisessä Satakunnassa ja Hämeessä mutti oli tarkoittanut myös hivenen hapatettua juomaa, joka tunnettiin myös nimillä pellonpiimä ja variko. Tätä vellimäistä juomaa oli valmistettu piimän sijaan, kun väki oli heinätöissä kaukana kotoa. Kuoritut perunat keitettiin vedessä ja sotkettiin hienoksi, minkä jälkeen liemeen sekoitettiin ruis(imelä) jauhoja ja kuuma vesi. Seoksen annettiin imeltyä saavissa. Prosessin aikana seos samalla hieman hapantui. Nimi variko kytkeytyy sanaan vari, 'keittoruoka', joka on venäjän kielestä itämerensuomalaiselle alueelle omaksuttu lainasana. Venäjän kielessä var' viittaa keittoruokaan, kun taas verbi varit' tarkoittaa 'keittää tai kuumentaa'. (Sanakirjasäätiön sanaliput; SSA; SKES.)

Pellonpiimästä eli juotavasta mutista on Sanakirjasäätiössä tarkkoja paikkatietoja Satakunnasta ja Hämeestä eli Asikkalasta, Heinolasta, Hollolasta, Jämijärveltä, Kärkölästä, Lammilta, Luopioisista ja Vanajasta (ks. kartan siniset pallot). Vaikuttaa siltä, että Sysmässä on juotavan mutin vaikutuksesta kutsuttu myös sahtia mutiksi. (Sanakirjasäätiön sanaliput.)

Mutti on siis ollut yksinkertainen ruoka, joka on varsinkin Pohjanmaalla ja Skandinavian suomalaismetsissä erotettu pepusta. Arvattavasti mitään yleisesti tunnettua kriteeriä ei ole ollut, mutta oheinen typologia selvittänee käsitteiden välisiä suhteita.

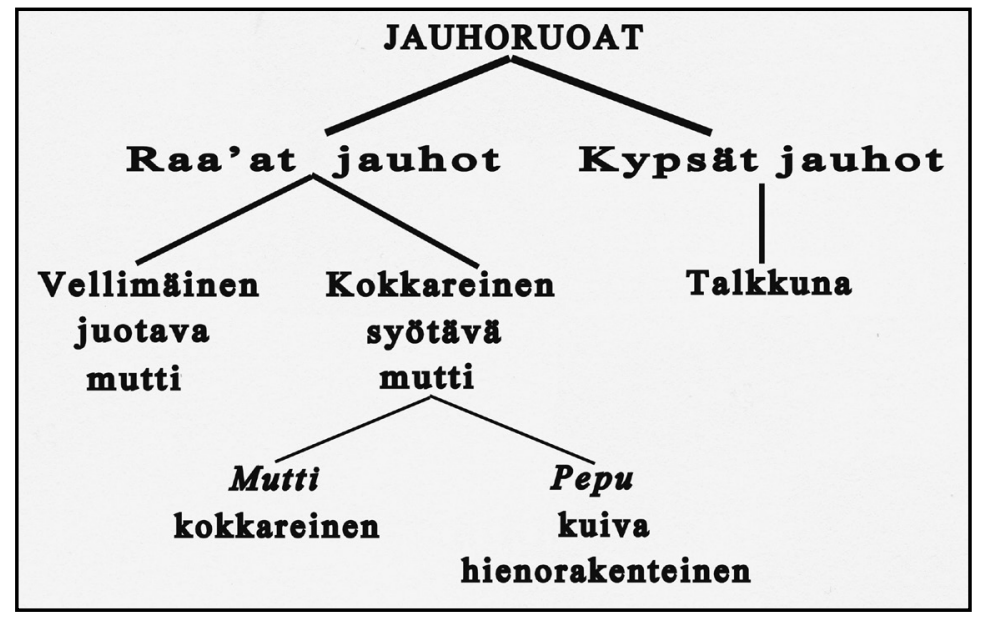

\section{TALKKUNA JA MÄMMI SUOMESSA}

Muttia ja pepua myöhäisempi jauhoruoka oli talkkuna, joka tehtiin talkkunaisista, esikeitetyistä ja kuivatuista jauhoista. Ilmar Talven mukaan Hämeen, Uudenmaan, Varsinais-Suomen, Ylä-Satakunnan Etelä-Pohjanmaan, Keski-Suomen ja Savon talkkuna oli sakeahko, piimään tai maitoon sekoitettu sekaviljavelli, jota syötiin lusikalla. Toisaalta likimain Kokkolasta Jyväskylään ja Viipuriin vedetyn linja itäpuolella talkkuna tehtiin keittämällä talkkunaiset vedessä. Tuloksena ollut sakea tahdas syötiin sormin ottamalla möykky astiasta ja kastamalla se rasvaan. Toki idässäkin talkkuna oli saatettu valmistaa sekoittamalla talkkunaiset maitoon tai piimään. Vienasta Aunuksen kautta Tihvinän ja 
Tverin Karjalaan veteen tai maitoon keitetty talkkuna oli nimeltään linta, l'inda. (Talve 1976 \& 1979; Vuorela 1976.)

Aasian mongolit ja turkkilaiset olivat vanhastaan valmistaneet viljansa paahtamalla ja keittämällä jyvät, jotka vasta kuivatuksen jälkeen jauhettiin jauhoiksi. Talkkuna oli kuulunut jo varhaiseen slaavilaiseen kulttuuriin, jossa sen nimi oli lainaa turkista eli mahdollisesti hunneilta tai bolgaareilta. Itämerensuomalaisissa kielissä talkkuna on lainaa myöhäiskantaslaavista eli varhaisesta venäjästä. Suomessa se oli levinnyt aina ruotsinkielistä rannikkoa myöten (talkon). Talkkunan tunsivat myös virolaiset, joten Suomeen kyseinen ruokalaji oli levinnyt karjalaisten ja mahdollisesti virolaisten välittämänä. Kiintoisasti virolaisten vellimäisen sekaviljatalkkunan nimi kama palautuu Pihkovan venäjän sanaan 'paakku' tai 'kokkare', joka tuo mieleen mutin. Näyttää selvältä, että talkkuna oli sekä ruokana että sanana alkanut levitä Suomeen keskiajan lopulta alkaen, mutta se tuskin oli merkittävästi ehtinyt pesiytyä savolaisten syntysijoille Mikkelin ympäristöön vielä 1500-luvun alkupuolella.

Mämmi assosioituu pääsiäisajan lounaissuomalaiseksi paastoruoaksi, mutta sillä on merkittävästi vanhempi esikristillinen menneisyys. Alkuaan mämmi oli (ruis)jauhoista imelletty tahdas, josta tehtiin yhtältä ruokaa ja toisaalta sahtia. Väinö Voionmaa on teoksessaan Hämäläisten eräkausi tehnyt pitkään selkoa erämiesten eväistä, joista yksi oli ollut mämmi. Tähän viittaa hämäläisten erämiesten käyttämien vesiteiden varsilla oleva Mämmi-nimistö aina Pohjanmaata myötä. Näitä olivat muun muassa Luopioisten Mämminlahti, Laukaan Mämminniemi, Äänekosken Mämmenkoski ja Säämingin Mämmilampi. Miehet eivät voineet kuljettaa mukanaan suuria tavaramääriä, mutta kylläkin jauhoja, jotka sekoittaa veteen ja kuumentaa varta vasten kyhätyssä tuohiropposessa. Mämmi-nimet ovat muistumia paikoista, joihin kulkijat olivat pysähtyneet lepäämään ja syömään. (Voionmaa 1947, 268-276.) Mielestäni on todennäköistä, että mämmi oli aikoinaan sana, joka oli hyvinkin voinut olla sekä mutin että pepun synonyymi. Voionmaan julkaiseman tiedon mukaan Sääksmäeltä vuonna 1520 kaukometsälle lähteneen nelikon mukaan oli varustettu muun muassa 200 litraa rukiita jauhoiksi ja 300 litraa ohria maltaiksi ja jauhoiksi (Voionmaa 1947, 268-276). Tämä nostaa esille kysymyksen olivatko siis mutti ja mämmi käsitteinä selkeästi erillään jo tuolloin? Epäilen, että nelimiehinen joukko olisi ryhtynyt Mämminiemessä imellyttämään ruisjauhojaan saadakseen syötävää, kun mutti olisi valmistunut tuossa tuokiossa. Mämmi olisi siis joskus aiemmin voinut olla mutin rinnakkaisnimitys.

Toisaalta on muistettava, että pepu liittyy laajempaan sanaryppääseen (peperö, pöperö), jolla oli viitattu jauhoista ja murskatuista marjoista keittämättä valmistettuun tahnamaiseen seokseen, joka syötiin sellaisenaan kylmänä. Pepu saattaa siis olla hyvin vanha sana ja miksei siis yhtä vanha kuin jyvien jauhaminen ja pelkän jauhon syönti.

\section{KOKKAREISEN MUTIN KAKSI VALMISTUSTAPAA}

Mutti on siis Suomessa valmistettu kahdella eri tavalla: hämmentämällä ja hämmentämättä. Alajärveltä saapuneen keskipohjalaisen selostuksen mukaan muttia valmistettaessa 
odotettiin, kunnes vesi kiehui kuplina eli oli ryöpässä. Kiehumisen jälkeen pataan kaadettiin ohrajauhoja ja niitä alettiin hämmentää voimakkaasti "hierimen väärällä päällä eli varrella”, kunnes vesi imeytyi jauhoihin. Tuloksena oli kokkareinen tai ryynimäinen, kuiva ja hieman ruskistunut ruoka, jota syötiin kourin piimän tai maidon kanssa. (Sanakirjasäätiön sanaliput: s.v. mutti.)

Tämän valmistustavan laajuudesta ei ole tietoa, mutta sillä on selkeästi yhteys Ruotsin puolen tavalle käyttää "muttimelaa”. Keskeistä oli hämmentää (ohra)jauhoja siihen asti, että vesi oli imeytynyt. Härkkimen varrella oli hämmennetty myös Kannuksessa, jossa seokseen oli lisätty voita. Hämmentäminen kuului siinä määrin asiaan, että muistitiedossa kerrotaan kerran lapsen komentaneen laiskanpuoleista mutinlaittajaa kutkuttamaan seosta, jotta siitä tulisi kunnollista. Pohjoisempana Kalajoella tunnettu verbi tamputtaa oli tarkoittanut 'mutin hämmentämistä, ja siellä muistetussa laulussa todetaankin, että "kyllä kaikki puuron keittää, vain ei taija tamputtaa”. Reisjärveläisen ohjeen mukaan puoleen litraan vettä pantiin 2 kiloa ohrajauhoja, minkä jälkeen seosta piti hämmentää puolisen tuntia kepillä, kunnes vesi oli imeytynyt ja mutti kypsynyt sopivan ruskeaksi.

Keräämieni tietojen mukaan toista valmistustapaa on käytetty muun muassa KeskiSuomen Karstulasta sekä Pohjois-Pohjanmaan Vihannista ja Kärsämäeltä. Tässä valmistusprosessissa hämmentämistä ei sallittu ollenkaan. Ohra- ja ruisjauhot sekoitettiin veteen ja mukaan lisättiin suolaa sekä rasva. Kärsämäellä ruisjauhot ruskistettiin paistinpannussa ja vasta sitten höyrystettiin. Kuivaan muttiin voitiin lisätä sianlihaa tai voita. Höyrystettäessä ruskistettuun jauhoseokseen paineltiin tikulla reikiä joihin vesi kaadettiin. Jos vesi loppui kesken, paineltiin seokseen uusia reikiä ja pataan lisättiin vettä seokseen muutoin koskematta. Jauhot oli voitu ruskistaa myös kattilassa, johon vesi oli kaadettu vasta ruskistamisen jälkeen. Tämä toinenkin tapa tunnettiin myös Ruotsin suomalaismetsissä, joissa oli paikoin todettu, että kokin tuli olla toimessaan "laiska".

Professori Helmi Järviluoma-Mäkelä toimitti minulle seuraavan ohjeen pohjoispohjalaisen Ylivieskan pepusta 1980-luvun loppupuolella:

Yhtä kahvikupillista vettä kohti tulee kaksi kahvikupillista ohrajauhoja sekä suolaa. Otetaan paksupohjainen kattila tai rautapata. Vesi kiehautetaan, suolataan ja ohrajauhot kaadetaan veden pinnalle. Ei sekoiteta. Kauhalla pistellään pepuun muutama reikä. Kansi päälle. Ei sekoiteta. Annetaan kiehua noin 20 minuuttia. Kun vesi ei enää pursua rei' istä eikä ilmivettä enää ole, pepu hierretään oikein hyväksi.

Hyvä pepu on pientä murua. Jos vettä jää, rakeista tulee isompia. Mutti tehdään muuten samalla tavalla, mutta vettä 1,5 desilitraa. Nautitaan voin ja maidon kera.

(Kirje Helmi Järviluomalta tammikuussa 1987.)

Järviluoma oli saanut tiedon ylivieskalaiselta Silja Säilyltä 25.12.1986. Tämän mukaan pepu oli joka talon ruoka niin Ylivieskassa kuin Nivalassakin vielä 1930-luvulla. Tuolloin sitä nautittiin eineeksi eli aamulla kahdeksan yhdeksän maissa vähintään kerran viikossa. Nykyään sitä syödään yhä silloin tällöin. Noin 1950- ja 1960-luvuilla alettiin 
lisätä ruokalusikallinen rasvaa ja syöminen harveni pariin kertaan kuukaudessa. (Kirje Järviluomalta 1987.)

\section{SANASTA MUTTI JA VÄHÄN MUUSTAKIN}

Pepu liittyy maalailevaan pöperö-sanaryppääseen, joka puolestaan on tarkoittanut yksinkertaista jauho- ja vesiruokaa. Tällaisena se oli omaksuttu myös suomenruotsiin ( peber tarkoittaa 'silppua' ja liivin kielessä, jossa bebbərz viittaa 'kuohkeaan'. Karjalan kielessä vaikutteet näkyivät verbissä pepelteä, jolla viitattiin sotkemiseen tai mylläämiseen, sekä substantiiveista pepoine, jolla tarkoitettiin 'heikkoravinteista syötävää kuten pettu'. Pepru taas viittasi 'rikkaan' tai 'roskaan' ja pöpettšy 'huonosti kohonneeseen leipään'. Päpelo tarkoitti 'möykkyä' (ruokaa tms.)' ja päppä(ine) 'leipää' lastenkielessä. (KKS.) Tämä viittaa siihen, että deskriptiiviset $p e-, p \ddot{a}-, p \ddot{o}-$-alkuiset sanat assosioituvat helposti itämerensuomessa sekoitettuun ja yksinkertaiseen syötävään, mutta niin selkeärajaista käsitettä kuin pepu ei kielialueen länsiseutujen tapaan ollut.

Mutti sanan jäljittäminenkin on hankalaa. Karjalaisissa yhteyksissä mutti, joka viittasi 'pikkukalaan', liittyy itämerensuomalaisten mutiainen-pesyeeseen. Sanassa on nähtävissä liitoksia myös 'mutaan', mutta tämä on lingvistisesti epävarma (vrt. sammakonpoika mutaojassa). Toinen karjalankielinen mutti liittyi 'mustaan koiraan' samaan tapaan kuin suomenkielinen Musti-sana tai nimi. Suomen kielestäkin löytyy muutama deskriptiivinen ilmaus, joita ei voida kytkeä mutti-ruokaan. Ainoa sanahistoriallinen selitys tälle sanalle näyttäisi olevan venäjän mutít', joka tarkoittaa 'hämmentää' tai 'sekoittaa' vettä tai velliä. Mutit'-verbistä voidaan johtaa mut', joka viittaa 'sameaan liemeen'. Näistä on johdettu abstrakti verbi smutit', 'hämmentää, sekoittaa mieltä', josta juontaa muun muassa karjalan smuutta. Se tarkoittaa 'silmänkääntäjää' ja 'vekkulia'. Jos muttia ei määritetä deskriptiivisanaksi — mikä mielestäni on perusteetonta — sen voi liittää venäjän 'vetelään sotkuun' mut'. (SSA \& SKES - s.v. mutti.)

Mutin aineellisena lähtökohtana on jyvä, joka uralilainen sana on indoiranilainen laina ja oli alkuaan tarkoittanut oluenkin perusainesta eli ohran jyvää. (Nenetsin $j \bar{a}$ merkitsee sekä 'jauhoa' että 'jauhokeittoa'.) Monet arkaaiset lainasanat kuten itää, kaski ja huhta viittaavat kaskiviljelyyn, joka niukkamultaisissa metsissä oli ainoa vaihtoehto. ${ }^{2}$ Verbit keittää ja kiehua lienevät molemmat varhaiskantasuomen vartalon *keje- johdoksia (SSA). Tällainen vartalo saattaa mielestäni olla laina Itä-Baltiassa puhutusta ja sittemmin kadonneesta muinaiskielestä, mahdollisesti samasta josta oli lainattu esimerkiksi salo 'suuri saari' ja helmi. Tavalla tai toisella tehtyjä liemiä oli valmistettu jo kivikauden lopussa, joten on kysyttävä, mitä ihmeen uutta vuosituhannen takaisten itäslaavien syömä mut' olisi voinut tarjota itämerensuomalaisille? Toisaalta on kysyttävä, mitä ruokaa esivanhempamme olivat tehneet opittuaan jauhamaan ohranjyvät ennen kuin he tutustuivat Länsi- 
Euroopan germaanien leipään? Leipähän paistettiin (germaaninen termi) alkuaan ilmeisesti kuumilla hiilillä, sittemmin kehystetyssä tulisijassa eli liedellä (germaaninen termi) ja lopulta tulella kuumennetun laakean kiven päällä eli hellalla (ruotsalainen termi). Jauhojen paistaminen leiväksi on siis nuorempi keksintö kuin jauhojen keittäminen esimerkiksi tuohesta taiteillussa ropposessa. Voiko tuloksena olla muuta kuin (a) liemi, jossa veteen sekoitettiin kalaa tai lihaa, tai (b) juotava mutti, jossa veteen sekoitettiin jauhoja, tai (c) kokkareinen mutti, jonka ytimenä oli jauhoon höyrystynyt vesi?

\section{PÄ̈̈TELMï̈}

Tilanne on jokseenkin hämmentävä, voisimme siis sanoa muttimainen. Selkeästi hyvin vanhalla, kivi- ja pronssikautisella, ruokalajilla näyttäisi olevan keskiajan venäläistä perua oleva nimi: mut, josta siis juontuu mutti. Toisaalta mutista olevien tietojen levikki vaikuttaa ristiriitaiselta. Jos mutti, eli kokkareiseksi höyrystetty jauhoruoka, olisi yhtä vanha kuin jauhojen valmistus ja käyttö, niin miksi tästä nelituhatvuotisesta ruoasta ei ole oikeastaan mitään selkeää savolaista tai karjalaista versiota, jonka voisi liittää muttiin. Kuitenkin mutin veivät keskiseen Skandinaviaan - sekä sanana että ruokana - ne finnet, joille se oli välttämätön eli kirveellä metsissä leipänsä hankkineet kaskiviljelijät ja ennen kaikkea savolaiset kaskiviljelijät.

Esille nousee myös kysymys, mikä mutissa oli sellaista, joka oikeuttaisi olettamasta mutti-sanan venäläiseksi ? On ilmeistä, että sana on jäänyt pois käytöstä yhdessä ruoan kanssa itäisen väestön omaksuttua talkkunan, joka taas oli metsäsuomalaisille tuntematon. Mutin kaltainen kokkareinen, kuivahko ruoka oli epäilemättä tunnettu Itä-Baltiassa (siis Itämeren itärannoilla $)^{3}$ jo kauan ennen kansainvaelluksia, jolloin slaavit elivät vielä eteläisessä Ukrainassa. Tuon ruoan omaperäinen nimi lienee jo pronssikaudella ollut рери-рӧрегӧ. On muistettava, että läntisimmän Värmlannin metsäfinnien kulttuurissa vanha karjalaisuus ja hämäläisyys ovat vahvasti läsnä, kun taas (murretta lukuun ottamatta) Suomen nykysavolaisten perinteinen kulttuuri on Värmlannissa läsnä heikosti. Tutkittuani tuon alueen metsäsuomalaisten lauluja vuonna 1996 kävi ilmeiseksi, että 1500-luvun ja paljolti myös 1600-luvun savolaisuus oli vielä karjalais- ja hämäläisvoittoista, mutta samoina vuosisatoina itsenäisesti omaperäinen savolaisuus oli kuitenkin jo syntymässä. Tätä uutta suomensavolaisuutta Skandinaviaan muuttaneet eivät ehtineet omaksua, joten he olivat vieneet mukanaan vanhemman karjalais-hämäläisen savolaisuuden. Se pohjautui vahvasti kaskeamiseen ja metsästykseen sekä myöhemmin metsurien töihin. Tällöin rasvan kanssa syöty kokkareinen mutti soveltui yli neljä vuosisataa erinomaisesti metsäfinnien energiapitoiseksi päiväruoaksi.

Kun itämerensuomalaiset olivat omaksuneet venäläisen talkkunan, pöperö jäi sen varjoon ja unohtui suomensavolaistenkin keskuudessa. Sen sijaan se säilyi vanhinta savolaista kulttuuria ylläpitäneillä alueilla eli Keski-Suomen Rautalammin suurpitäjän länsiosassa, Etelä-Pohjanmaan järviseudulla sekä Keski-Skandinaviassa. Muttia ei tunnettu eteläisellä Etelä-Pohjanmaalla, mutta kyllä savolaiskiilassa ja sen pohjoispuolella 
eli siis Keski-Pohjanmaalla ja Pohjois-Pohjanmaan eteläosassa.

Mikä siis selittää lainan mut' > mutti? Arvelen, että karjatalouden vahvistuessa 1500-luvulta alkaen vuotuinen heinäntarve kasvoi ja samalla heinätöiden määrä lisääntyi. Kun talkkuna alkoi idässä syrjäyttää kuivan pöperön, varsinkin kuumina kesäpäivinä työskenneltäessä juotava pöperö oli omaksuttu heinäntekijöiden juomaksi ja vahvaksi välipalaksi. Slaavien vellimäistä jauhojuomaa ei liene aiemmin tarvittu, mutta tällaisen juoman asema kesähelteissä tapahtuneen raskaan heinän- ja viljankorjuun aikaisena välipalana sai niin suuren suosion, että se omaksuttiin ennen kaikkea peltoviljely- ja karjanhoitoalueella eli Hämeessä ja Pohjanmaalla. Samean jauhojuoman mukana kieleen tarttui sana mutti.

Tämän seurauksena vellimäisen, juotavan mutin rinnalla säilyi samoista aineksista samoin menetelmin valmistettu kokkareinen pöperö, jota oli niin ikään alettu kutsua mutiksi erotuksena modernimmasta talkkunasta. Tämä prosessi lienee tapahtunut savolaisten länsipuolella eli Hämeessä ja itäisessä Satakunnassa, nykyisellä Pirkanmaalla (ks. kartta). Mutti oli sanana levinnyt Pohjanmaalle ilmeisesti Hämeen kautta, vaikka se kuivana oli jo vanhastaan tunnettu pepu-pöperönä. Koska Pohjanmaalla käytettiin kahta sanaa, pepu ja mutti, tarkoittamaan samaa ruokaa, alkoivat ihmiset näillä alueilla tehdä eroa ruokien kuivuusasteen välillä. Ero näkyy esimerkiksi Helmi Järviluoma-Mäkelän ylivieskalaisreseptistä: pepussa on yksi kuppi vettä kahta jauhokuppia kohden, kun taas mutissa vettä on puolitoista kuppia, jolloin siitä tulee kosteaa. Finnet tunsivat molemmat sanat, mutta eron kriteerit olivat alkaneet horjua niin, että originaalista penkkivellistä tuli pepua, kun taas kuiva ruoka oli muttia. Alkuperäisen tiedon mukaisesti Reisjärveltä kotoisin ollut Matti kertoi Internetissä vuonna 2009: "Meillä ko ruoan nimi oli pepu ja epäonnistunutta pepua kutsuttiin [vellimäiseksi] mutiksi. Olen keittänyt täällä Australiassakin pepua lukuisia kertoja." (Soppakauha 2012.)

\section{ViITTEeT:}

1. Kuunteluesimerkki Pekka Lumiaisen musiikista löytyy osoitteesta http://www. youtube.com $/$ watch? $\mathrm{v}=\mathrm{XUmPCN9q8OQ \& feature=}=\mathrm{relmfu}$ ja esimerkki Pekka Tiaisen musiikista löytyy osoitteesta http://www.youtube.com/watch?v=XtEhEJaxG4\&feature=related

2. Tässä kohden on painotettava, että pellossa kasvupohjana on multa, kun taas kaskessa (huhdassa) kasvupohjana on tuhka! Täten siis kaski ei voi olla pelto, sanovat biologian opettajat mitä tahansa.

3. Esimerkiksi arkeologit puhuvat aina Itä-Baltiasta, kun tarkoittavat Itämeren itärantoja jolloin Länsi-Baltia olisi Ruotsi. Termi edustaa paikallisia erikoisuuksia, joka aiheutuu Länsi-meren kutsumisesta sekä Itä-mereksi että Baltian mereksi. 
Timo Leisiö: Mutti ja pepu

\section{LÄHTEET:}

Kirjallisuus:

BERGMAN, JONAS: Något om kosten i Hälsingland under äldre tid. Ljusdal: Ljusdals Hembygdsgård. (Ei painovuotta)

BLADH, GABRIEL 1995: Finnskogens landskap och människor under fyra sekler. Högskolan i Karlstad Forskningsrapport 95:11.

DAL', VLADIMIR 1989-1991 (1880-1882):Tolkovyj slovar' živogo velikorusskogo jazyka I-IV. [Faksimile] Moskva: Russkij jazyk.

ELES, HÅKAN (red.) 1995: Skogsfinnarna och Finnskogen. Torby: Finnkulturcentrums skrifter 1.

HUURRE, MATTI 1979: 9000 vuotta Suomen esibistoriaa. Helsinki: Otava.

HÄKKINEN, KAISA: Suomalaisten esihistoria kielitieteen valossa. Tietolipas 144. Helsinki: Suomalaisen Kirjallisuuden Seura.

KANGASNIEMI, SEPPO 1992: Jos mutti epäonnistuu, siitä tulee peppua. - Aamulehti 29.7.1992.

KARVINEN, VÄINÖ 1939: Aineksia pohjoissavolaisen kansanomaisen ruokatalouden tutkimukselle. Viidennet museopäivät Kuopiossa 1938. Helsinki.

KKS: Karjalan kielen sanakirja. Osat I-IV. Toimittanut Pertti Virtaranta, Raija Koponen et al. Helsinki 1968-1993: Suomalais-ugrilainen Seura.

KOKKONEN, JOUKO \& SUUTARI, PEKKA 2006: Talakkunassa on voema ja terveys. Savo-Karjalaisen Osakunnan talakkunajuhla 120 vuotta. Tallinna: Jouko Kokkonen.

KUUSI, MATTI 1980: Kalevalaista kertomarunoutta. Helsinki: Suomalaisen Kirjallisuuden Seura.

LAMPINEN, AINO 1976: 52. Varijuuri ja karjalainen mämmi. - Suomen kansankulttuurin kartasto I. Helsinki: Suomalaisen Kirjallisuuden Seura.

LEISIÖ, TIMO 1995a: Gottlund, Pippingsköld, Poppius ja kolme sävelmää. - Musiikki, 1, s. $29-45$.

LEISIÖ, TIMO 1995b: Kulturell stabilitet och förändring. Tre exempel. - Finlands svenska folk-musikinstitutets småskrifter nr. 2. Red. Anders G. Lindqvist. Vasa.

LEISIÖ, TIMO 1996: Metsäsuomalaisten varhaisia sävelmätallenteita Östmarkin pitäjästä, Värmlannista. - Etnomusikologian vuosikirja 8. Turku.

MANNINEN ILMARI 1934: Ruoka, juoma, nautintoaineet. - Suomen suku III. Helsinki.

MÄGISTE, JULIUS 1953: Om värmlandsfinska lånord i den värmländska dialekten. - Värmland för och nu. Karlstad: Värmlands Museum.

NORDMANN, PETRUS 1994: Finnarne i Mellersta Sverige. Faksimilupplaga efter originalutgåva tryckt 1888. Malung: Dalaförlaget.

RAUN, ALO 1982: Eesti keele etümoloogiline teatmik. Tallinna: Maarjamaa.

RÄSÄNEN, MARTTI 1980: Savokarjalainen ateria. Keuruu: Otava.

SALO, UNTO 1986: Kalevala, kansanrunous ja historia. - Kalevalaseuran vuosikirja 66. Helsinki : Suomalaisen Kirjallisuuden Seura. 
SKES: Suomen kielen etymologinen sanakirja I-VI. Helsinki: Suomalais-ugrilainen Seura $1955-1981$.

SSA: Suomen sanojen alkuperä. Etymologinen sanakirja 1-3. - Kulonen, Ulla-Maija et al. (toim.) Helsinki 2000-2001 (1992, 1995, 2000): Kotimaisten kielten tutkimuskeskus ja Suomalaisen Kirjallisuuden Seura.

TALVE, ILMAR 1973: Suomen kansanomaisesta ruokataloudesta. Turku: Turun yliopiston kansatieteen laitoksen toimituksia 2.

TALVE, ILMAR 1979: Suomen kansankulttuuri. Historiallisia päälinjoja. Helsinki: Suomalaisen Kirjallisuuden Seuran Toimituksia 355.

TARKIAINEN, KARI 1990: Finnarnas historia i Sverige 1. Inflyttarna frän Finland under det gemensamma rikets tid. Stockholm: Nordiska museets Handlingar 109.

TERNHAG, GUNNAR 1978: Leisme Per Larsson. - Otavan iso musiikkitietosanakirja 4. Porvoo-Helsinki.

TURESSON, GUNNAR 1964: Värmländska kulturtraditioner. Del III. Finsk odling, dikt och musik. Stockholm.

VOIONMAA, VÄINÖ 1947: Hämäläinen eräkausi: Porvoo-Helsinki: WSOY.

VUORELA, TOIVO 1975: Suomalainen kansankulttuuri. Porvoo-Helsinki: WSOY.

VUORELA, TOIVO 1976: Talkkuna. - Sarmela, Matti (toim.), Suomen kansankulttuurin kartasto 1. Helsinki: Suomalaisen Kirjallisuuden Seuran Toimituksia 587.

VUORELA, TOIVO 1979: Kansanperinteen sanakirja. Porvoo-Helsinki-Juva: WSOY.

\section{Digitaaliset lähteet:}

FINNSKOGARNA 2012: http://finnskogarna.com/skogsfinnarnas-matkultur/

KARMENKYNNA 2012: http://www.lekvattnet.nu/Karmenkynna/index.asp

SOPPAKAUHA 2012: http://www.soppakauha.com/index.asp?s=/reseptit/1375.htm STÖPAFORSKVARN 2012: http://www.stopaforskvarn.se

Timo Leisiö työskenteli Tampereen yliopistossa musiikintutkimuksen professorina 29 vuotta. Tällä hetkellä Leisiö kirjoittaa neurologien tuloksille pohjaavaa universaaliteoriaa siitä, miten ihmisen musiikkia voi tutkia välittämättä kulttuurisista erilaisuuksista. 